\author{
Suvorova S. A., \\ Candidate of Philological Sciences, Associate Professor, \\ English Language Teacher at the Department of Foreign Languages \\ Prydniprovska State Academy of Civil Engineering and Architecture
}

\title{
TEXT CHARACTERISTICS OF THE SCIENTIFIC STYLE AS ONE OF THE FUNCTIONAL STYLES OF SPEECH
}

\begin{abstract}
Summary. The relevance of this article is to emphasize the constructiveness of the scientific style of speech, the basic unit of which is a term that denotes a scientific concept with high accuracy and a high degree of generalization. Also a "double" thematic chain, typical of many scientific papers. In the article, we analyzed the combination of thematic and key vocabulary, words with the highest usage rates. In today's world of high scientific technology, scientific communication has gained global significance. Summarizing all that has been said about the thematic chains of the scientific text, let us note their structural and content certainty: as the main nomination, they consistently use the basic one, in the composition of non-main nominations the most significant are folded transforms, after which, significantly inferior to them in frequency, there are substitutes. Semantically and stylistically, the thematic chains of a scientific text are uniform, they have a bookish character, since these chains are defined by a term and implemented on its basis. Comparison of the use of the terms cyclization and cycle in this text shows that the second of them, being no less frequent in the text, is used mainly as a means of segmentation in the middle of the article and especially when it comes to research material. The differences in the composition of the nomination chains of the main theme are insignificant. To the named structural types of nominations, one can single out the main nominations of the text chain, add only grammatical transformations. Thus, in this article we can note the status of the base unit as the main in the text. The nature of the information entered and the compositional role properties of bundles that are equally relevant for a scientific text. A certain uniformity is also observed in the field of combinatorics of the linguistic components of the scientific thematic chain.
\end{abstract}

Key words: constructive principle, scientific language, substyle, functional style, thematic chain, vocabulary, structure, nomination.

The constructive principle of scientific speech is generalization, abstraction, accuracy, which is due to the scientific type of thinking and the abstracted addressee and addressee of the text [1]. The author of a scientific text strives for self-elimination in favor of the subject of speech, never fully achieving this goal. A rational program in a scientific text prevails over an evaluative one (with the exception of certain genres, for example, reviews) and is distinguished by its extensiveness, analyticity, and logical thoughtfulness. As for the pragmatic program, it is different for the sub-styles of scientific speech. Two positions of the scientific text are possible: the addressee is approximately equal to the author in terms of the level of special knowledge (the situation of the scientific sub-style proper), and the addressee is a person trained by the author in this area of knowledge (the situation of the educational-scientific sub-style). In the second case, the pragmatic program becomes equal in importance to the rational one and is characterized by specific means of expression. The educational and scientific substyle is not considered in this work [2]. The features of the thematic chain of a scientific text are closely related to the constructive attribute of the style. The basic unit here, as a rule, is the term denoting a scientific concept with high precision and a high degree of generalization. The lexico-semantic composition of the thematic chain of a scientific text is rather modest. In addition to the basic unit (for example, a functional style), it includes periphrases based on a generic concept (this kind of language / speech); transforms, among which the most common are collapsed nominations of two varieties - collapsed to the pivot word of the base phrase (style), often with indicative qualifiers (this style, this style), and folded into an abbreviation (FS = functional style). The scientific text does not use zero nominations; any nominations with stylistic markings, except for the book, are extremely rare. The role of the main nomination in the text chain belongs to the basic nomination, it is also the primary one, and, as a rule, it is realized already in the title of the scientific text. The text functions of the members of the thematic chain are the function of identifying the subject of speech, as well as the function of general text communication: distantly located nominations of the main subject of speech work for the integrity of the text.

Let us follow in more detail the organization of the thematic chain, taking into account the following circumstance of its identification: only units of equal conceptual volume were included in the thematic chain. The nominations of sub-concepts (for example, for our case, the vocabulary of a functional style) are included in the thematic field of the text, but are not included in the thematic chain of the whole text, making up its branch. In the text "On the functional semantic and stylistic categories of the text", the basic nomination-phrase (a) is included in the heading. In addition to it, the following nominations are marked: these categories (b), named categories (c), considered categories (d), functional categories (e), categories (f), they (g). A schematically depicted thematic chain is as follows *: AA b A b Ac Ag Adg Agd AbAde Af

The chain contains only three types of nominations: basic (terminological), collapsed transforms and pronominal substitutes[3]. There is no doubt about the status of the basic unit as the main one in the text (ten repetitions, including in the title and the beginning of the main part of the article, while the maximum repetitions of other nominations is three). The periodicity of nominations of different structural and semantic types is clearly visible. In the absence of rigidly ordered alternations, none of them is repeated more than two times, and the main nomination is constantly interspersed with additional ones. This chain structure is typical for texts in various branches of science. 
Differences in the composition of the nomination chains of the main theme are insignificant. To the named structural types of nominations, one can single out the main nominations of the text chain, add only grammatical transformations (anglicisms - anglicism, shaman costumes - shaman costume) [4]. We can speak of referentially identical nominations only in cases where the subject of discussion is material (relevant for archeology, ethnography, geology and similar sciences); synonyms in the field of special vocabulary are extremely undesirable and are rare (shamanic costume - shamanic clothing). The most common structural type of the thematic chain nominations, after the direct (basic) nomination, should be considered the transformative type [5]. For its implementation, scientific texts have clichéd constructions of an indicative-connecting type: given, considered, named, indicated, canceled (phenomenon, concept, etc.), for example: this theorem, considered anglicisms, indicated effect, etc.

It should be noted that the nomination of the subject of speech in an exclusively lexical (nominative-lexical) way in a scientific text is not obligatory. A free textual description is also possible here, blurring to some extent the severity of the nominative thematic chain. For example, in the text "On the Question of Anglicisms in Modern Spanish" the descriptive-textual input of one of the subteses looks like this: Some English influence is also found at the syntactic level of Spanish speech. However, this method is clearly additional and can be reduced to the first. So, the given example can be easily transformed by introducing the basic term Anglicisms: Anglicisms are also found at the syntactic level [6]. A more complex organization of the thematic chain is observed in the case when the author operates not one, but two basic nominations that are close to each other. For example, in the text "Cyclization in modern prose" these are the nominations of cyclization and cycle, which are related to each other as designations of the process and its result: cyclization is the formation, the formation of the cycle [7]. To prove the existence of a cycle means to prove the phenomenon of cyclization, therefore the author uses both terms, sometimes completely equating them (For a lyrical miniature, cyclization becomes a natural form). At the same time, the leading one is only one of the terms - cyclization, which is emphasized not only by its introduction into the title, but also by its role in the structural and semantic segmentation of the text.

Comparison of the use of the terms cyclization and cycle in this text shows that the second of them, being no less frequent in the text, is used mainly as a means of segmentation in the middle of the article and especially when it comes to research material. Its role decreases towards the end of the text, while the role of the problematic term cyclization increases[8]. The function of the latter as introducing a large structural-semantic fragment of the text corresponding to a subtopic is obvious: in four cases out of six, the term cyclization is located in the initial phrases of paragraphs and in connection with a large theoretical concept of the genre; within the limits of each fragment, the author sequentially operates with the terms cycle, cyclic unity. "Scale", the fundamental role in the whole text is a more significant text quality than the mechanically calculated frequency, and when determining the main nomination it should be taken into account first of all.

It should be noted that the "double" thematic chain described above is typical for many scientific works, which is associated with the delineation of the topic as an object, research material and topic as a problem / The problem chain is organized on the basis of a term, that is, it has a significative basis, object-thematic - is associated with a certain phenomenon of reality and often rests on the referential identity of the nominations [9]. Thus, in the text "Thematic and Key Words in the Language of Russian Poetry of the 19th Century. Review of the works of G. Hetso 197-1985" a chain with the basic nomination of the Norwegian Russianist Geir Hetso and additional ones: G. Hetso (15 uses), he (5), scientist (1) Norwegian scientist (1), researcher (1) is clearly traced [10]. This is an object-topic chain, very important in the review article genre. Along with it, a problem-thematic chain appears in the text with a basic terminological combination of thematic and key words and additional nominations: thematic and key vocabulary, she, words with the highest usage rates.

Summarizing all that has been said about the thematic chains of the scientific text, let us note their structural and substantive certainty: the basic category is consistently used in them as the main nomination; in the minor nominations, folded transforms are the most significant, after which, significantly inferior to them in frequency, there are substitutes. Semantically and stylistically, the thematic chains of a scientific text are uniform, they have a bookish character, since these chains are defined by a term and implemented on its basis. A certain uniformity is also observed in the field of combinatorics of the linguistic components of the scientific thematic chain [11]. The latter is characterized by the frequency of use of the main nomination and the relative variety of non-main nominations alternating with it (the non-main nominations of the thematic chain repeated in the text are almost never found side by side). The phenomenon of a "double" thematic chain is quite typical for a scientific text [12]. Chains of the train of thought of a scientific text A scientific text is characterized by the explication of the logical development of thought and, as a result, by an abundance of means of logical division and a relatively long length of chains of the train of thought.

What are the features of the linguistic expression of chains train of thought? It is noticeable that the unmarked -fragments are the initial and, less often, the final sections of the structural and content unity corresponding to one of the developing theses of the text, and the internal connections in this unity are explicated using various logical connectives. Most information links have relatively short action length, establishing relationships between adjacent or close text fragments. "Long-range" links, organizing the textual connection of distantly located fragments, are allocated to the group of compositional-textual links. The nature of the information entered and the compositional role properties of bundles that are equally relevant for a scientific text. Linguistic bundles are often arranged in pairs, and compositional signals precede informational ones: attention should be paid here; the above example; let's move on to the most essential phenomenon. They can form pairs and ligaments of a subjective-logical and objective-logical nature, for example: it is not surprising, for example. Units of the same type are rarely grouped, although one of them is frequent: so, for example. The lexical structure of thought chains is very elastic. Here synonymy and variance of forms are developed [13]. Perhaps there is no bundle, which could not be replaced by a synonym or variant-transform, for example: according to this, according to this, according to this; so, thus, in the end, at the exit; so, for example, we give an example, turn to illustrations, serve as an illustration. This gives the author of a scientific text a certain - and considerable - scope for achieving diversity, and if it is small for someone, then you can look for more 
original ways to convey the idea of a logical connection of a certain type, which is observed in some scientific works [14]. Thus, the means of logical connections of a scientific text are harmonized with respect to standard / non-standard: standardness prevails in it, but the ramification of variants and the possibility of individual speech variation based on the standard meaning deprives the text of excessive rigidity, a standard raised to a principle.

\section{References:}

1. Акишина А. Л. Структура цілого тексту: У 2 ч. М., № 79. Ч. 1. 89 c; Ч. 2.81 c.

2. Барт Р. Текстовий аналіз. Нове в зарубіжній лінгвістиці. Москва, 1980. C. 307-312.

3. Барикіна А.І., Бурмістрова В.П., Добровольська В.В. Посібник з розвитку навичок писемного мовлення. Москва, 1978. $190 \mathrm{c}$.

4. Гак В.Г. Повторна номінація і iї стилістичне використання. Питання франиузької філології. Москва, 1972. С. 123-136.

5. Гак В.Г. Про семантичної організації тексту. Лінгвістика тексту: Матеріали науч. конф.: У 2 ч. М., 1974. Ч. 1. С. 61-66.

6. Гак В.Г. До типології лінгвістичних номінацій. Мовна номінація: Загальні питання. Москва, 1977. С. 230-293.

7. Дридзе Т.М. Текст як ієрархія комунікативних програм: (інформативно-цільовий підхід). Смислове сприйняття мовного повідомлення. Москва, 1976. С. 48-57.

8. Дешеріева Т.І. Лінгвістичний аспект категорії часу в його відношенні до фізичного і філософському аспектах. Зап. мовознавства. 1975. № 2. C. 111-117.

9. Івін А.А. Підстави логіки оцінок. Москва, 1970. 230 с.

10. Леонтьев А.А. Висловлювання як предмет лінгвістики, психолінгвістики та теорії комунікації. Синтаксис тексту. Москва, 1979. C. $18-36$.

11. Ляпон М.В. До питання про мовну специфіку модальності. Изв. Сер.шт. і яз. 1971. Т. 30, № 3. С. 230-239:

12. Майданова Л.М. Нариси 3 практичної стилістики для студ.-журналістів Свердловськ, 1986. 184 с.

13. Мамалига А.І. Структура газетного тексту. Київ, 1983. 137 с.

14. Мете Н.А., Митрофанова О.Д., Одинцова Т.Б. Структура наукового тексту і навчання монологічного мовлення. Москва, 1981. $144 \mathrm{c}$.

15. Мостепаненко А.М. Проблема універсальності основних властивостей простору і часу. Ленінград, 1969. 229 с.

16. Новиков А.І. Семантика тексту і iï формалізація. Москва, 1983. $215 \mathrm{c}$.

17. Откупщикова М.Н. Деякі закономірності розпізнавання зв'язного тексту. Лінгвістичні проблеми функиіонального моделювання мовної діяльності. Ленінград, 1982. Вип. 5. С. 21-41.

18. Откупщикова М.I. Синтаксис зв'язного тексту: (Структурна лінгвістична модель) : Автореф. дис. ... д-ра філол. наук. Ленінград, 1987. 33 с.

19. Різун В.В. Про тему тексту і тематичної групи слів: Теоретичний аспект. Мова і композиція газетного тексту: Теорія і практика. Свердловськ, 1987. С. 32-37.
20. Сметаніна С.І. Функціонально-типологічний аналіз способів найменування осіб і фактів в структурі публіцистичного тексту : Автореф. дис. ... канд. філол. наук. Ленинград, 1982. 16 с.

21. Смислове сприйняття мовного повідомлення: (в умовах масової комунікаціі). Москва, 1976. 263 с.

22. Стриженко А.А., Кручинина Л.І. Про особливості організації текстів, що відносяться до різних функціональних стилів. Іркутськ, $1985.176 \mathrm{c}$.

23. Телія В.Н. Коннотатівний аспект семантики номінативних одиниць. Москва, 1986. 142 с

24. Тункель В.Д. До питання про усній передачі мовного повідомлення: Дис. ... канд. філол. наук. Москва, 1964.

25. Тураєва 3.Я. Лінгвістика тексту. Москва, 1986. 126 с.

Суворова С. А. Текстові характеристики наукового стилю як одного 3 функціональних стилів мови

Анотація. Актуальність цієї статті полягає в тому, щоб підкреслити конструктивність наукового стилю мовлення, базовою одиницею якого виступає термін, який позначає наукове поняття 3 високою точністю і високим ступенем узагальнення. Також «подвійний» тематичний ланцюжок типовий для багатьох наукових робіт. У статті ми проаналізували поєднання тематичної і ключовий лексики, тобто слова $з$ найвищими коефіцієнтами вживання. У сучасному світі високих наукових технологій наукове спілкування набуло глобального значення. Узагальнюючи все про тематичні ланцюжки наукового тексту, відзначимо їх структурно-змістовну визначеність: як основна номінація в них послідовно використовується базова, в складі неосновних номінацій найбільш значимі згорнуті трансформи, після них, істотно поступаючись їм в частотності, йдуть субститути. У семантико-стилістичному відношенні тематичні ланцюжки наукового тексту одноманітні, їм властивий книжковий характер, оскільки дані ланцюжка задаються терміном і реалізуються на його базі. Порівняння вживань термінів циклізация і цикл в цьому тексті показує, що другий 3 них, будучи не менш частотним в тексті, використовується в основному як засіб сегментації в середній частині статті і особливо коли йдеться про матеріал дослідження. Відмінності в складі номінаційних ланцюжків основної теми незначні. До названих структурних типів номінацій можна виділити основні номінації текстової ланцюжка, додати лише граматичні трансформи. Добре помітна періодичність номінацій різних структурно-семантичних типів. За відсутності жорстко впорядкованих чергувань жодна 3 них не повторюється більше двох разів, а основна номінація постійно перемежовує додаткові. Така будова ланцюжка типова для текстів різних галузей науки. Таким чином, у цій статті ми зможемо відзначити статус базової одиниці як основної в тексті.

Ключові слова: конструктивний принцип, наукова мова, підстиль, функціональний стиль, тематичний ланцюжок, лексика, структура, номінації. 